\title{
Production and action of an Aspergillus phoenicis enzymatic pool using different carbon sources
}

\author{
Produção e ação de um pool enzimático de Aspergillus phoenicis \\ com fontes de carbono diferentes
}

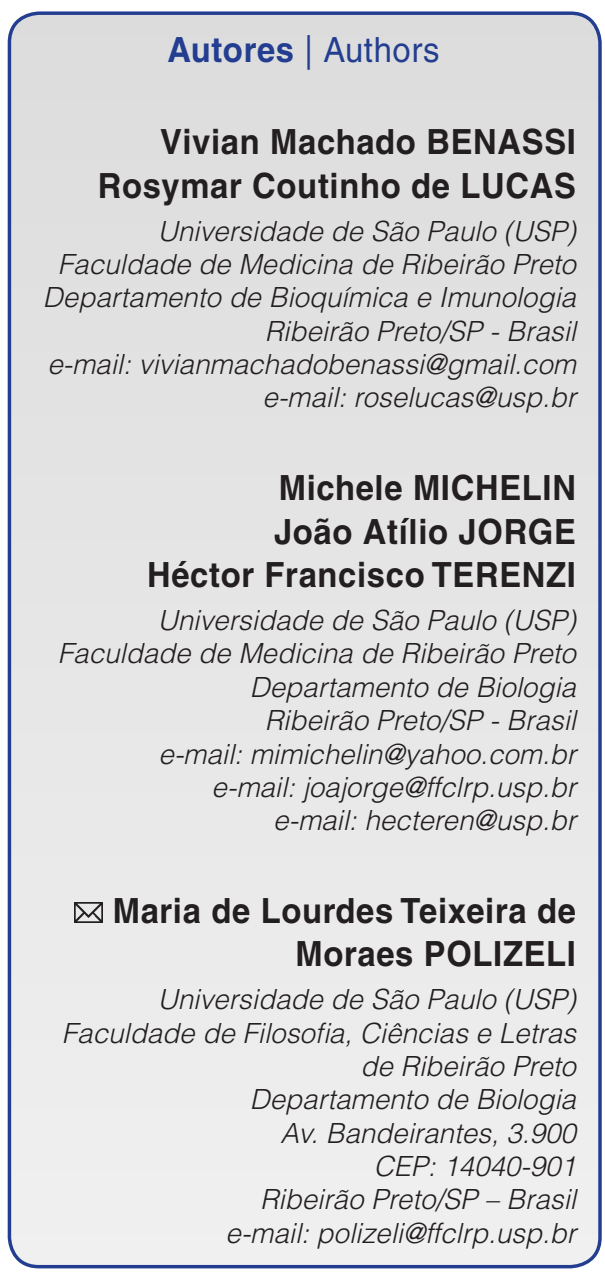

$\square$ Autor Correspondente / Corresponding Author

Recebido / Received: 08/02/2011 Aprovado / Approved: 07/03/2012 Publicado / Published: set./2012

\section{Summary}

Aspergillus phoenicis is an interesting heat tolerant fungus that can synthesize enzymes with several applications in the food industry due to its great hydrolytic potential. In this work, the fungus produced high enzymatic levels when cultivated on inexpensive culture media consisting of flakes from different origins such as cassava flour, wheat fibre, crushed soybean, agro-industrial wastes, starch, glucose or maltose. Several enzymatic systems were produced from these carbon sources, but amylase was the most evident, followed by pectinase and xylanase. Traces of CMCases, avicelase, lipase, $\beta$-xylosidase, $\beta$-glucosidase and $\alpha$-glucosidase activities were also detected. Amylases were produced on rye flakes, starch, oat flakes, corn flakes, cassava flour and wheat fibre. Significant amylolytic levels were produced in the culture medium with glucose or when this sugar was exhausted, suggesting an enzyme in the constitutive form. Cassava flour, rye, oats, barley and corn flakes were also used as substrates in the hydrolytic reactions, aiming to verify the liberation potential of reducing sugars. Corn flakes induced greater liberation of reducing sugars as compared to the others. Thin layer chromatography of the reaction end products showed that the hydrolysis of cassava flour liberated maltooligosaccharides, but cassava flour and corn, rye, oats and barley flakes were hydrolyzed to glucose. These results suggested the presence of glucoamylase and $\alpha$-amylase as part of the enzymatic pool of A. phoencis.

Key words: Aspergillus phoenicis; Amylase; Rye flakes; Potato starch; Cassava flour.

\section{Resumo}

Aspergillus phoenicis é um fungo termotolerante interessante, uma vez que pode sintetizar enzimas com diversas aplicações em indústrias alimentícias em função de seu grande potencial de hidrólise. Neste trabalho, verificou-se que esse fungo produziu níveis enzimáticos elevados, quando o mesmo foi cultivado em meio de cultura de baixo custo, constituído de flocos de diferentes origens, como farinha de mandioca, fibra de trigo, soja triturada, resíduos agroindustriais, amido e glicose ou maltose. Diversos sistemas enzimáticos foram produzidos a partir dessas fontes de carbono, mas a amilase foi a mais evidente, seguida de pectinase e xilanase. Traços de atividades de CMcases, avicelase, lipase, $\beta$-xilosidase, $\beta$-glicosidase e $\alpha$-glicosidase também foram detectados. Amilases foram produzidas em flocos de centeio, amido, flocos de aveia, flocos de milho, farinha de mandioca e fibra de trigo. Níveis amilolíticos significantes foram produzidos em meio de cultura contendo glicose ou quando esse açúcar não estava mais presente, sugerindo uma forma constitutiva dessa enzima. Farinha de mandioca, flocos de centeio, aveia, cevada e milho também foram utilizados como substratos nas reações de hidrólise, com o objetivo de verificar a potencial liberação de açúcares redutores. Flocos de milho induziram maior formação de açúcares redutores, quando comparados com os outros substratos. A análise por cromatografia em camada delgada dos produtos finais da reação revelou que a hidrólise da farinha de mandioca liberou malto-oligossacarídeos, mas farinha de mandioca e flocos de milho, centeio, aveia e cevada foram hidrolisados até glicose. Esses resultados sugeriram a presença de glucoamilase e $\alpha$-amilase como parte da mistura enzimática de A. phoenicis.

Palavras-chave: Aspergillus phoenicis; Amilase; Flocos de centeio; Amido de batata; Farinha de mandioca. 


\section{Introduction}

Amylases are widely distributed in nature and play an important role in the starch-processing industry (GOTO et al., 1998). These enzymes are used in the food industry to improve final product quality, working to increase bread softness and volume. In addition, they promote the formation of a crispy crust on the bread surface and change its colour, thus attracting more consumers. Moreover, once bakery products are ready, they start to undergo changes leading to quality deterioration due to aging. These changes include shrinkage, less crispy skin, brownish colour and loss of flavour. One way to delay such process is to add various additives during bread production. Several types of de-branching and branching amylases have been suggested as anti-aging agents, for example: $\alpha$-amylase, maltogenic-amylases, $\beta$-amylase and glucoamylases. During several types of bread manufacturing, amylases are added together with other enzymes, and thus the carbon sources, such as wheat fibre, rye flakes, barley flakes, cassava flour and others, are degrading more quickly. The sugars formed are promptly fermented by yeasts, releasing a considerable amount of carbon dioxide via anaerobic metabolism, consequently increasing bread softness and volume (GUPTA et al., 2003).

The main reasons for using enzymes in industrial processes are cost effectiveness, less time consuming processes, less space requirement and ease of modifying and optimizing the process (BANO et al., 2011). Microorganisms have been considered the best source of enzymes, since some of these microbes are able to grow at high temperatures and produce more heat stable enzymes, which are frequently more resistant and more efficient as catalysts than homologous proteins synthesized by mesophilic microorganisms (RIZZATTI et al., 2004). The fungi are frequently amongst the best enzyme producers, and Aspergillus phoenicis is an example of a heat tolerant fungus which grows well at $42^{\circ} \mathrm{C}$ (RIZZATTI et al., 2001). This fungus was isolated from sugar cane bagasse from areas near sugar cane plantations, and has been shown to be an excellent producer of enzymes such as, for example, beta-xylosidase (RIZZATTI et al., 2001) and xylanase (RIZZATTI et al., 2004).

Trade and food industry waste produces substantial amounts of peel, seeds, kernel and other residues. These materials are rich sources of organic matter, such as protein, carbohydrate and essential oils, which can be used as substrates to produce enzymes by microbial fermentation (BAIG et al., 2004). Vandenberg et al. (2000) noted that the enrichment of a culture medium with cassava bagasse encouraged the growth of Aspergillus niger. Bravo et al. (2000) reported the use of sugar cane bagasse as a carbon source for microbial growth in the production of enzymes for applications in the fruit juice, wine, cocoa and coffee industries. Moreover, other researchers are using residues such as cassava root for the production of amylases (SILVA et al., 2009). It is important to remember that monomers, such as glucose, xylose, arabinose and others, can be used as inducers in the production of some enzymes, but this property varies for each type of fungus (ARO et al., 2005). In Trichoderma reesei, for example, the best yields of $\beta$-xylosidase were obtained when xylose was used as the inducer (KNOB et al., 2010). Arabinose induced the expression of a set of genes of Aspergillus niger that encoding for enzymes involved in the degradation of arabinoxylan (ARO et al., 2005), and xylose oligomers induced xylanase activity in Trichoderma longibrachiatum (ROYER and NAKAS, 1990). Thus, the aims of this study were to analyze the production of various enzymes from $A$. phoenicis using different carbon sources as inducers, and investigate the hydrolytic potential of the enzymatic systems produced and their end-products.

\section{Material and methods}

\subsection{Microorganism and strain maintenance}

A. phoenicis was isolated from sugar cane bagasse in decomposed material from the region of Ribeirão Preto - São Paulo, Brazil. The microorganism was identified as described by Raper and Fennell (1965) and Klich and Pitt (1988), using the nucleotide sequence analysis of ribosomal genes (rDNA), in particular the ITS (Internal Transcribed Spacer Sequence) spacer region. Species identification was based on similarity of over $96 \%$ and deposited in NCBI with the accession number: FJ810504. The microorganism was maintained on slants of complete Vogel medium (VOGEL, 1964). The inoculum consisted of a conidia solution prepared in sterile distilled water, which was added to the medium at a final concentration of $10^{5}$ conidia/mL of culture medium.

\subsection{Growth conditions}

The most suitable conditions for amylase production were found to be in $\mathrm{MB}$ (Machado Benassi) medium, initial $\mathrm{pH}$ 6.0, standardized in the authors' laboratory. The fermentation process was carried out in conical flasks containing the following liquid medium $\left(0.1 \mathrm{~g} \mathrm{NH}_{4} \mathrm{NO}_{3}\right.$; $0.065 \mathrm{~g} \mathrm{KH}_{2} \mathrm{PO}_{4} ; 0.0181 \mathrm{~g} \mathrm{MgSO}_{4}$. $7 \mathrm{H}_{2} \mathrm{O} ; 0.0049 \mathrm{~g} \mathrm{KCl}$; $0.00035 \mathrm{~g} \mathrm{ZnSO}_{4} .7 \mathrm{H}_{2} \mathrm{O} ; 0.00069 \mathrm{~g} \mathrm{MnSO}_{4} . \mathrm{H}_{2} \mathrm{O} ; 0.0033 \mathrm{~g}$ $\mathrm{FeCl}_{3} .6 \mathrm{H}_{2} \mathrm{O} ; 0.000031 \mathrm{~g} \mathrm{CuSO}_{4} .5 \mathrm{H}_{2} \mathrm{O} ; 0.025 \mathrm{~g}$ yeast extract; $0.25 \mathrm{~g}$ carbon source and $25 \mathrm{~mL}$ distilled water). Different carbon sources were tested at a concentration of $1 \%$. Growth occurred statically in a bacteriological incubator for four days at $30{ }^{\circ} \mathrm{C}$. The culture was then harvested by filtration through Whatman $n^{\circ} 1$ filter paper, and the filtrate used as a source of extracellular amylolytic activity. The mycelial mass ( $\mathrm{g}$ ) was determined by weighing of the mycelium after it has been dried in 
bacterial incubator. The mycelia pads obtained were ground in a mortar in an ice bath with 2 volumes of glass beads and suspended in $100 \mathrm{mM}$ sodium acetate buffer, $\mathrm{pH}$ 5.0. The slurry was centrifuged at $12,000 \mathrm{~g}$ for $15 \mathrm{~min}$ at $4{ }^{\circ} \mathrm{C}$ and the supernatant was the source of intracellular enzyme.

\subsection{Protein and enzymatic activity determinations}

The protein content was determined according to Lowry et al. (1951), with bovine serum albumin as the standard. The enzymatic activities were estimated using different substrates and the formation of reducing sugars quantified using 3,5-dinitrosalicylic acid (DNS) (MILLER, 1959). For the determination of amylase activity, the assay was carried out at $65^{\circ} \mathrm{C}$ with a mixture containing $250 \mu \mathrm{L}$ of a solution of $1 \%$ potato starch in $100 \mathrm{mM}$ sodium acetate buffer, pH 5.0 and $250 \mu \mathrm{L}$ of diluted enzyme. Aliquots $(100 \mu \mathrm{L})$ were withdrawn after different time intervals (15 and $30 \mathrm{~min}$ ), and the assay tubes covered with parafilm and boiled for $5 \mathrm{~min}$. The tubes were then chilled and $1 \mathrm{~mL}$ of distilled water added. The blanks consisted of $100 \mu \mathrm{L}$ of reaction mixture with the immediate addition of $100 \mu \mathrm{L}$ of DNS. The diastatic control was performed by incubating the substrates in $100 \mathrm{mM}$ sodium acetate buffer, $\mathrm{pH} 5.0$, for $30 \mathrm{~min}$ at $65^{\circ} \mathrm{C}$, and no reducing sugars were detected. The absorbance readings were made at $540 \mathrm{~nm}$ using a microplate. Glucose was used as the standard $\left(0.1\right.$ to $\left.1.0 \mathrm{mg} \cdot \mathrm{mL}^{-1}\right)$ and one unit of enzyme activity $(U)$ was the amount of enzyme required to produce one $\mu \mathrm{mol}$ of reducing sugar per minute per $\mathrm{mL}$ under the test conditions.

In order to determine the xylanase, CMCase, avicelase and polygalacturonase activities, $1 \%$ birchwood xylan, sodium carboxymethylcellulose - medium viscosity, avicel and sodium polypectate were used as substrates, respectively. The method was standardized using xylose (xylanase), glucose (CMCase and avicelase) and monogalacturonic acid (polygalacturonase) (0.1 to $1.0 \mathrm{mg} \mathrm{mL}^{-1}$ ), as previously described by PeixotoNogueira et al. (2009). The total activity was defined as the amount of enzyme required to produce one $\mu \mathrm{mol}$ of reducing sugar $/ \mathrm{min} / \mathrm{mL} x$ total extracellular or intracellular filtrate volume. The specific activity was expressed as the total $\mathrm{U} /$ total $\mathrm{mg}$ protein of the mycelia extract (U.mg-1 prot.).

\subsection{Determination of enzymatic activity using synthetic substrates}

The hydrolytic action of various enzymes was analyzed according to Somera et al. (2009) using $2.0 \mathrm{mM}$ $p$-nitrophenyl- $\beta$-D-glucopyranoside ( $\beta$-glucosidase), $p$-nitrophenyl- $\alpha$-D-glucopyranoside ( $\alpha$-glucosidase), $p$-nitrophenyl- $\beta$-D-xyloside ( $\beta$-xylosidase) and p-nitrophenyl-palmitate (lipase). The enzyme mixture consisted of $200 \mu \mathrm{L}$ of $100 \mathrm{mM}$ sodium acetate buffer, pH 5.0, $50 \mu \mathrm{L}$ of synthetic substrate and $100 \mu \mathrm{L}$ of enzyme and the assay was carried out at $60^{\circ} \mathrm{C}$ at determined time intervals (10 and $20 \mathrm{~min}$ ). The reaction was interrupted by adding $1 \mathrm{~mL}$ of a saturated solution of sodium tetraborate. A control was prepared by substituting the enzyme with distilled water. The absorbance was read at $540 \mathrm{~nm}$ using a microplate count and the method was standardized using $p$-nitrophenol ( 0.1 to $\left.1.0 \mathrm{mg} \cdot \mathrm{mL}^{-1}\right)$ as the standard. One unit of enzyme activity $(U)$ was the amount of enzyme required to produce one $\mu \mathrm{mol} p$-nitrophenol per minute per $\mathrm{mL}$ under the test conditions.

\subsection{Chromatography of hydrolysis products}

Thin layer chromatography (TLC) was used to analyze the hydrolysis products of the amylases. A volume of $5 \mu \mathrm{L}$ of the reaction mixture was applied to silica gel plates (DC-Alufolien Kieselgel 60, Merck), and subjected to two consecutive ascending chromatographic runs using butanol/ethanol/water (5:3:2) as the solvent system. After air-drying the plates, the spots were developed by spraying with $\mathrm{H}_{2} \mathrm{SO}_{4}$ and methanol (1:9) containing $0.2 \%$ orcinol, and heating at $100{ }^{\circ} \mathrm{C}$ (FONTANA et al., 1988). A mixture of (1\%) glucose, maltose, maltotriose, maltotetraose and maltopentaose was applied as the standard.

\section{Results and discussion}

\subsection{Effect of carbon sources on the production of amylase}

In order to evaluate the effects of different carbon sources on the production of amylase, the MB culture media were supplemented with different carbon sources. No carbon source was added to the control (Table 1). A. phoenicis exhibited variable mycelial protein and the best levels were noted in the medium supplemented with maltose, potato starch, glucose and cassava flour. With respect to the amylolytic activities (extracellular + intracellular), the carbon sources that resulted in the greatest amylase productions were: rye flakes (8.7-times), potato starch (8.6-times), oat flakes (7.7-times), as well as corn flakes, cassava flour, wheat fibre, glucose, maltose and barley flakes (average of 7.3-times in relation to the control). The majority of the sources contributed to the secretion of amylase activity, since the extracellular activities were approximately $90 \%$ of the sum of the extracellular and intracellular activities. The agro-industrial residues used were probably hydrolyzed in the culture medium to smaller compounds (maltodextrins) by constitutive amylases, which are located in the fungal cell wall. The intracellular transport of maltooligosacharides through the membrane is provided 
Table 1. Effect of the supplementation of different carbon sources on the growth and production of amylase by Aspergillus phoenicis.

\begin{tabular}{|c|c|c|c|c|}
\hline Carbon source $(1 \%)$ & Extracellular (total U) & $\begin{array}{l}\text { Amylolytic Activity } \\
\text { Intracellular (total U) }\end{array}$ & Total Extra + Intra & Protein (total mg) \\
\hline No carbon source & $124 \pm 0.045$ & $8 \pm 0.02$ & 132 & $0.5 \pm 0.002$ \\
\hline Glucose & $794 \pm 0.034$ & $175 \pm 0.01$ & 969 & $6 \pm 0.001$ \\
\hline Starch & $993 \pm 0.018$ & $140 \pm 0.098$ & 1133 & $6 \pm 0.003$ \\
\hline Maltose & $763 \pm 0.013$ & $185 \pm 0.014$ & 949 & $6 \pm 0.002$ \\
\hline Rye flakes & $1048 \pm 0.013$ & $102 \pm 0.023$ & 1150 & $2 \pm 0.001$ \\
\hline Cassava flour & $890 \pm 0.007$ & $103 \pm 0.067$ & 992 & $6 \pm 0.012$ \\
\hline Oat flakes & $889 \pm 0.033$ & $132 \pm 0.023$ & 1021 & $4 \pm 0.022$ \\
\hline Wheat fibre & $881 \pm 0.040$ & $99 \pm 0.014$ & 980 & $5 \pm 0.003$ \\
\hline Barley flakes & $880 \pm 0.007$ & $27 \pm 0.039$ & 907 & $0.2 \pm 0.001$ \\
\hline Corn flakes & $861 \pm 0.014$ & $134 \pm 0.049$ & 995 & $0.7 \pm 0.004$ \\
\hline Crushed soybean & $565 \pm 0.028$ & $110 \pm 0.054$ & 675 & $4 \pm 0.002$ \\
\hline Soy flakes & $181 \pm 0.010$ & $27 \pm 0.013$ & 208 & $5 \pm 0.027$ \\
\hline Corn cob & $102 \pm 0.012$ & $10 \pm 0.009$ & 112 & $1 \pm 0.003$ \\
\hline Sugar cane bagasse & $72 \pm 0.011$ & $18 \pm 0.020$ & 90 & $0.5 \pm 0.003$ \\
\hline
\end{tabular}

The samples were obtained from $25 \mathrm{~mL}$ of MB liquid culture medium after 4 days of incubation at $30^{\circ} \mathrm{C}$ under static conditions. The measurements were carried out with $1 \%$ starch substrate in $100 \mathrm{mM}$ sodium acetate buffer, $\mathrm{pH}$ 5.0, and the protein values were expressed as $\mathrm{mg}$ total protein of the mycelial sample. (All experiments were done in triplicate and the average values reported).

by permeases, which are specific dependent transporters. The maltooligosacharides may act as true inducers of the gene expression. According to Carlson (1987), fermentation of the oligosaccharides is controlled by repetitive gene families that are dispersed, such as SUC (Sucrose), MAL (Maltose) and MGL ( $\alpha$-Methylglucosides). Each family includes functionally equivalent multiple loci that control the fermentation ability. There are many reports of using food sources to produce enzymes. Balkan and Ertan (2010) used three carbon sources (wheat bran, rice husks and sunflower oil meal) to check for the production of $\alpha$-amylase by Penicillium brevicompactum, and noted that all the substrates supported growth but that the sunflower oil meal did not support enzyme production. On the other hand, wheat bran showed the highest activity.

Table 1 also shows the production of amylase by A. phoenicis in a culture medium with no carbon source. This was probably due to salts, proteins and vitamins derived from the yeast extract. On the other hand, the description of glucose as a catabolic repressor acting on the regulation of gene expression at transcriptional levels is classic in the literature (CARLSON, 1987). The amylase of $A$. phoenicis is apparently a constitutive enzyme, as previously reported for the $\beta$-glucosidase from Humicola grisea var. thermoidea (POLIZELI et al., 1996).

\subsection{Analyses of the hydrolysis of the different substrates}

After observing the excellent levels of amylolytic activity, it was of interest to analyze the enzymatic hydrolysis potential with food sources. Thus extracellular extracts produced from the different carbon sources were incubated with solutions of $1 \%$ crushed soybean, cassava flour, corn flakes, oat flakes, soy flakes, wheat fibre, sugar cane bagasse, barley flakes, corn cob and rye flakes in $100 \mathrm{mM}$ sodium acetate buffer, $\mathrm{pH}$ 5.0, as described in the methods section. The amount of reducing sugars formed after 30 min of reaction time was determined (Table 2), and the results obtained showed that the enzymes secreted when the fungus was grown on cassava flour were capable of hydrolyzing rye flakes, soy flakes, cassava flour and oat flakes (average activity of $141 \mathrm{U} \cdot \mathrm{mL}^{-1}$ ), and also when barley flakes were used as the source for fungal growth.

The amylolytic enzyme showed a high rate of hydrolysis with barley flakes, rye flakes, crushed soybean and oat flakes as substrate (average of $143 \mathrm{U} \cdot \mathrm{mL}^{-1}$ ). When rye flakes were used to produce the enzyme, the enzymatic pool hydrolyzed cassava flour and rye flakes as substrates (average activity of $151 \mathrm{U} \cdot \mathrm{mL}^{-1}$ ), whereas practically no activity was detected on wheat fibre. The enzymes produced on corn flakes led to excellent formation of reducing sugar when the same source of carbon was used (357 U.mL ${ }^{-1}$ ), followed by hydrolysis on barley flakes (187 U.mL $\mathrm{mL}^{-1}$ ), but wheat fibre was not efficiently hydrolyzed $\left(4 \cup \cdot \mathrm{mL}^{-1}\right)$.

The hydrolysis of oat flakes, wheat fibre, crushed soybean and sugar cane bagasse produced low concentrations of reducing sugar. These results can be explained based on the different proximate compositions and different morphological structures, For instance, sugar cane bagasse, which produced low amounts of hydrolysis products, contains almost $70 \%$ of carbohydrates in its composition, and its morphological structure is complex (ROSSELL, 2006). On the other hand, the best carbon sources used in this study were rye flakes, corn flakes and cassava flour showed different 
Production and action of an Aspergillus phoenicis enzymatic pool using different carbon sources BENASSI, V. M. et al.

Table 2. Hydrolysis of the different substrates.

\begin{tabular}{|c|c|c|c|c|c|c|c|}
\hline \multirow{3}{*}{ Substrates (1\%) } & \multicolumn{7}{|c|}{ Enzyme activity (total U) } \\
\hline & \multicolumn{7}{|c|}{ Inducing sources } \\
\hline & Cassava flour & Barley flakes & Oat flakes & Rye flakes & Corn flakes & Wheat fibre & $\begin{array}{l}\text { Crushed } \\
\text { Soybean }\end{array}$ \\
\hline Crushed soybean & $32 \pm 0.010$ & $143 \pm 0.013$ & $34 \pm 0.011$ & $17 \pm 0.004$ & $11 \pm 0.002$ & $24 \pm 0.002$ & $34 \pm 0.013$ \\
\hline Cassava flour & $114 \pm 0.010$ & $66 \pm 0.041$ & $56 \pm 0.013$ & $189 \pm 0.010$ & $75 \pm 0.047$ & $76 \pm 0.014$ & $92 \pm 0.048$ \\
\hline Corn flakes & $69 \pm 0.007$ & $59 \pm 0.012$ & $62 \pm 0.007$ & $62 \pm 0.014$ & $357 \pm 0.033$ & $71 \pm 0.010$ & $45 \pm 0.001$ \\
\hline Oat flakes & $112 \pm 0.006$ & $116 \pm 0.084$ & $112 \pm 0.062$ & $34 \pm 0.004$ & $73 \pm 0.018$ & $118 \pm 0.004$ & $77 \pm 0.030$ \\
\hline Soy flakes & $145 \pm 0.012$ & $21 \pm 0.003$ & $27 \pm 0.006$ & $41 \pm 0.0287$ & $26 \pm 0.012$ & $24 \pm 0.011$ & $20 \pm 0.011$ \\
\hline Wheat fibre & $49 \pm 0.014$ & $13 \pm 0.004$ & $11 \pm 0.011$ & $1 \pm 0.001$ & $4 \pm 0.007$ & $24 \pm 0.004$ & $34 \pm 0.010$ \\
\hline Sugar cane bagasse & $11 \pm 0.002$ & $8 \pm 0.002$ & $4 \pm 0.003$ & $71 \pm 0.034$ & $19 \pm 0.009$ & $10 \pm 0.006$ & $10 \pm 0.004$ \\
\hline Barley flakes & $40 \pm 0.007$ & $159 \pm 0.013$ & $164 \pm 0.014$ & $36 \pm 0.009$ & $187 \pm 0.012$ & $32 \pm 0.008$ & $93 \pm 0.007$ \\
\hline Corn cob & $21 \pm 0.008$ & $33 \pm 0.006$ & $11 \pm 0.008$ & $24 \pm 0.019$ & $64 \pm 0.048$ & $15 \pm 0.004$ & $22 \pm 0.007$ \\
\hline Rye flakes & $193 \pm 0.094$ & $153 \pm 0.065$ & $168 \pm 0.062$ & $113 \pm 0.029$ & $72 \pm 0.005$ & $101 \pm 0.003$ & $134 \pm 0.032$ \\
\hline
\end{tabular}

The fungus was added to $25 \mathrm{~mL}$ of $\mathrm{MB}$ liquid culture medium and incubated for 4 days at $30^{\circ} \mathrm{C}$ under static conditions. The measurements were carried out with $1 \%$ substrate in $100 \mathrm{mM}$ sodium acetate buffer, $\mathrm{pH}$ 5.0. (All experiments were done in triplicate and the average values were reported).

values (76.7 g carbohydrates. $100 \mathrm{~g}^{-1}$ food source and $1.07 \mathrm{~g}$ fibre. $100 \mathrm{~g}^{-1}$ food source) (DUTRA-DE-OLIVEIRA and MARCHINI, 2008). This result shows that, in general, the nutritional source used had good potential for the induction of enzyme synthesis by $A$. phoenicis, and that the enzyme pool produced could hydrolyze several food sources, suggesting the possibility of application in industrial saccharification processes.

\subsection{Evidence for the production of other enzyme activities from the carbon sources}

The substrates added to the culture media had complex compositions, which could stimulate the production of other enzymes that would be able to take part in the hydrolysis of the food sources. With the objective of knowing more about the complex enzyme systems produced, three extracts with high hydrolytic action were selected: corn flakes, cassava flour and rye flakes. Several enzyme activities were determined (Table 3 ) and it was observed that A. phoenicis produced significant levels of amylase under all conditions, followed by polygalacturonase and xylanase in smaller proportions. Traces of other enzymes were also detected but probably did not contribute significantly to the hydrolysis of the sources analyzed.

The results indicated that the enzymes produced by $A$. phoenics using food sources from agro-industrial residues, had industrial potential, mainly for the food industry. The possibility of using these enzymes is very interesting, since it could significantly reduce the production costs. Also, it must be considered that due to the complex composition, these residues could induce multiple enzymes, which would lead to greater levels of hydrolysis.

It is known that the supply of enzyme mixtures (xylanases, phospholipases, amylases, glucose oxidases),
Table 3. Enzyme activities using medium supplemented with different carbon sources.

\begin{tabular}{lccc}
\multicolumn{1}{c}{ Enzymes } & \multicolumn{3}{c}{$\begin{array}{c}\text { Enzyme activity (total U) } \\
\text { Inducer sources }\end{array}$} \\
& Corn flakes & Cassava flour & Rye flakes \\
Amylase & 866.52 & 887.37 & 1017.64 \\
Polygalacturonase & 122.04 & 145.53 & 161.88 \\
Xylanase & 84.24 & 71.28 & 163.02 \\
CMCase & 2.16 & 5.28 & 7.60 \\
Avicelase & 0.36 & 0.33 & 7.60 \\
Lipase* $^{*}$ & 0.36 & 0.33 & 0.38 \\
$\beta$-xylosidase* & 0.36 & 0.66 & 7.60 \\
$\beta$-glucosidase* & 1.08 & 1.32 & 1.52 \\
$\alpha$-glucosidase* & 1.44 & 1.65 & 1.90 \\
\hline
\end{tabular}

${ }^{*}$ Formation of $\mu$ mols of $p$-nitrophenol $/$ minute $/ \mathrm{mL}$. A. phoenicis was incubated in $40 \mathrm{~mL}$ of MB liquid culture medium with added corn flakes, cassava flour or rye flakes for 4 days at $30^{\circ} \mathrm{C}$ under static conditions. (All the experiments were done in triplicate and the average values were reported).

together with emulsifiers (polysorbates) is a common practice to equilibrate the flour quality in mills that produce pre-mixes for breads, cakes and biscuits, especially French bread, replacing the old chemical oxidants such as bromate and azodicarbonamides (ESTELLER et al., 2004).

\subsection{Effect of glucose as carbon source on the production of amylase}

An interesting result was obtained when glucose was used as the carbon source in the production of amylase (see Table 1). Relatively high levels of this enzyme were observed (total of $794 \mathrm{U}$ ), even though the carbohydrates were assimilated quickly by the microorganisms. This result is interesting because in most cases, glucose acts as a catabolic repressor. 
Production and action of an Aspergillus phoenicis enzymatic pool using different carbon sources

BENASSI, V. M. et al.

Thus the time-course of the production of amylase was monitored using $1 \%$ glucose as the carbon source during four days of fungal growth. The protein content of the mycelial extract (intracellular) and of the culture filtrate (extracellular), and also the mycelial mass and final $\mathrm{pH}$ of the cultivation medium were also monmitored (Table 4).

The mycelial mass increased up to the third day, and remained stable thereafter. Concomitant to this result, it was found that on the first two days the final $\mathrm{pH}$ of the medium was acidic (2.4-3.6), whereas on the third and fourth days, it was close to neutrality (6.2). Regarding the levels of intracellular proteins, a decrease of about $17.5 \%$ in the amount of protein was observed from the third to the fourth days, followed by an increase in extracellular protein $(97.6 \%)$ from the third to fourth days, suggesting enzymatic secretion.

The highest extracellular amylase activity occurred on the fourth day of cultivation. A decrease in the enzyme levels was observed from the second to third days with respect to the intracellular (15.3\%) and extracellular $(45.7 \%)$ activities, probably due to the accumulation of amylolytic hydrolysates of low molecular weight in the culture medium. The presence of high enzyme levels throughout the incubation period suggests constitutive amylolytic activity in the presence of glucose as the carbon source.

\subsection{Hydrolysis products of starch saccharification}

The enzymes produced when the fungus was grown on $1 \%$ corn flakes, rye flakes, oat flakes and cassava flour were incubated using several types of food source as substrates. The sugars formed after 2 and $24 \mathrm{~h}$ of saccharification were analyzed by thin layer chromatography (TLC). In these analyses, glucose was the only end product detected, suggesting the presence

Table 4. Effect of glucose as the carbon source on the growth and production of amylase by A. phoenicis.

\begin{tabular}{ccccccc} 
Days & $\begin{array}{c}\text { Mycelial mass } \\
\text { (g) }\end{array}$ & $\begin{array}{c}\text { Extracellular } \\
\text { pH }\end{array}$ & $\begin{array}{c}\text { Intracellular protein } \\
\text { (total } \mathbf{~ m} \text { ) }\end{array}$ & $\begin{array}{c}\text { Intracellular activity } \\
\text { (total U) }\end{array}$ & $\begin{array}{c}\text { Extracellular protein } \\
\text { (total mg) }\end{array}$ & $\begin{array}{c}\text { Extracellular activity } \\
\text { (total U) }\end{array}$ \\
\hline 1 & $1.48 \pm 0.013$ & 2.40 & $2.61 \pm 0.008$ & $237.14 \pm 0.006$ & $10.19 \pm 0$ & $1158.57 \pm 0.012$ \\
2 & $1.88 \pm 0.041$ & 3.60 & $5.70 \pm 0.008$ & $172.86 \pm 0.001$ & $3.02 \pm 0.006$ & $1263.04 \pm 0.001$ \\
3 & $2.01 \pm 0.067$ & 6.28 & $4.80 \pm 0.001$ & $146.43 \pm 0.012$ & $5.88 \pm 0.002$ & $685.54 \pm 0.012$ \\
4 & $1.98 \pm 0.020$ & 6.25 & $3.96 \pm 0.003$ & $201.43 \pm 0.011$ & $11.62 \pm 0.009$ & $1268.75 \pm 0.015$ \\
\hline
\end{tabular}

The fungus was grown in MB medium with added $1 \%$ glucose, under static conditions at $30{ }^{\circ} \mathrm{C}$, for different numbers of days. The values for total amylase activity were expressed in $\mu \mathrm{mols} / \mathrm{minute} / \mathrm{mL} \times$ volume of filtrate, and the protein values were expressed as $\mathrm{mg}$ total protein of the mycelial sample (intracellular) or medium filtrate (extracellular).
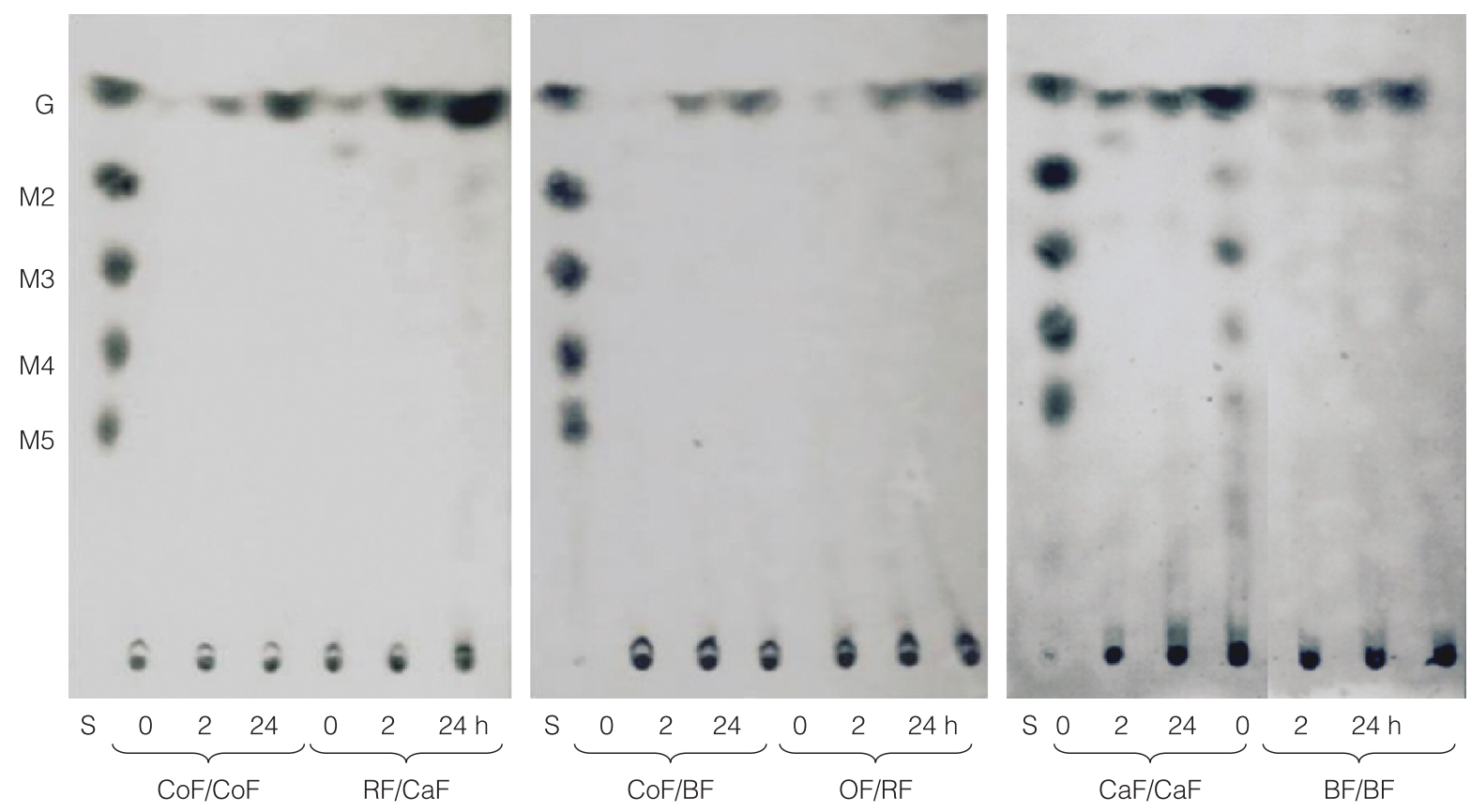

Figure 1. Thin layer chromatographic analysis. TLC of the hydrolysis products of amylases from A. phoenicis obtained with different carbon sources after $0 \mathrm{~h}$ (control), 2 and $24 \mathrm{~h}$. S- standard (G- glucose, M2- maltose, M3- maltotriose, M4- maltotetraose, M5-maltopentose). The abbreviations represent the food sources used as carbon source and as substrates for the enzymatic reactions, respectively. CoF/CoF- Corn Flakes/Corn Flakes; RF/CaF- Rye Flakes/Cassava Flour; CoF/BF- Corn Flakes/Barley Flakes; OF/RF- Oat Flakes/Rye Flakes; CaF/CaF- Cassava Flour/Cassava Flour; BF/BF- Barley Flakes/Barley Flakes. 
Production and action of an Aspergillus phoenicis enzymatic pool using different carbon sources BENASSI, V. M. et al.

of glucoamylase. On the other hand, in the presence of cassava flour as carbon source, several sugars were detected by TLC as the hydrolysis products, such as glucose, maltose, maltotriose, maltotetraose and maltopentaose, suggesting, in this case, the induction of both $\alpha$-amylase and glucoamylase (Figure 1).

\section{Conclusions}

The fungus $A$. phoenicis produced good amylase levels when the MB culture medium was supplemented with complex and inexpensive carbon sources. A close correlation was observed between the hydrolysis of certain substrates and the enzyme pool synthesized from inducers with complex compositions, the enzymes synthesized with major activities being amylase, polygalacturonase and xylanase.

Constitutive amylase was detected in the media containing glucose, as well as in non-inducing media supplemented with additional sources. The results suggest the application of the enzymes obtained from A. phoenicis in biotechnological processes, their use being of particular promise in the cereal area, especially in wheat milling, the processing of corn in the production of flours and the use of by-products (straw, bran) in the production of biofuel.

\section{Acknowledgments}

This work was financially supported by the Fundação de Amparo à Pesquisa do Estado de São Paulo (FAPESP, process number 2010/52322-3) and the Conselho de Desenvolvimento Científico e Tecnológico (CNPq) - INCT. J.A. Jorge and M.L.T.M. Polizeli each receive CNPq research fellowships. This work is part of the dissertation of Vivian Machado Benassi (VM Benassi, CNPq) for the Biochemistry Graduation Program at FMRP-USP. We are grateful to Ricardo Alarcon, Mariana Cereia and Mauricio de Oliveira for their technical assistance.

\section{References}

ARO, N.; PAKUIA, T.; PENTTILÃ, M. Transcriptional regulation of plant cell wall degradation by filamentous fungi. FEMS Microbiology Review, San Francisco, v. 29, n. 4, p. 719-739, 2005. http://dx.doi.org/10.1016/j.femsre.2004.11.006

BAIG, M. M. V.; BAIG, M. L. B.; BAIG, M. I. A.; YASMEEN, M. Saccharification of banana agro-waste by cellulolytic enzymes. African Journal of Biotechnology, Victoria Island-Lagos, v. 3, n. 9, p. 447-450, 2004

BALKAN, B.; ERTAN, F. The production of a new fungal $\alpha$-amylase degraded the raw starch by means of solid-state fermentation. Preparative Biochemistry \& Biotechnology, United Kingdom, v. 40, n. 3, p. 213-228, 2010. http://dx.doi.org/ 10.1080/10826068.2010.488549
BANO, S.; QADER, S. A. U.; AMAN, A.; SYED, M. N.; AZHAR, A. Purification and characterization of novel $\alpha$-amylase from Bacillus subtilis KIBGE HAS. AAPS PharmSciTech, New York, v. 12, n. 1, 255-261, 2011. http://dx.doi.org/10.1208/s12249011-9586-1

BRAVO, C. E. C.; CARVALHO, E. P.; SCHWAN, R. F.; GÓMEZ, R. J. H. C.; PILON, L. Determinação de condições ideais para produção de poligalacturonase por Kluyveromyces marxianus. Ciências e Agrotecnologia, Lavras, v. 24, p.137-152, 2000. Edição especial.

CARLSON, M. Regulation of sugar utilization in Saccharomyces species. The Journal of Bacteriology, Washington, v. 169, n. 11, p. 4873-4877, 1987

DUtRA-DE-OLIVEIRA, J. E.; MARCHINI, J. S. Ciências Nutricionais: Aprendendo a Aprender. 2. ed. São Paulo: Sarvier, 2008. 760 p.

ESTELLER, M. S.; YOSHIMOTO, R. M. O.; AMARAL, R. L.; LANNES, S. C. S. Uso de açúcares em produtos panificados. Ciências e Tecnologia de Alimentos, Campinas, v. 24, n. 4 , p. 602-607, 2004. Tabela 2. http://dx.doi.org/10.1590/S010120612004000400021

FONTANA, J. D.; GEBARA, M.; BLUMEL, M.; SCHNEIDER, H.; MACKENZIE, C. R.; JOHNSON, K. G. $\alpha$-4-O-methyl-Dglucuronidase component of xylanolytic complexes. Methods Enzymology, New York, v. 160, p. 560-571, 1988. http://dx.doi. org/10.1016/0076-6879(88)60169-8

GOTO, C. E.; BARBOSA, E. P.; KISTNER, L. C. L.; GANDA, R. F.; ARRIAS, V. L.; PERALTA, R. M. Production of amylase by Aspergillus fumigatus. Revista de Microbiologia, São Paulo, v. 29, p. 99-103, 1998.

GUPTA, R.; GIGRAS, P.; MOHAPATRA, H.; GOSWAMI, V. K.; CHAUHAN, B. Microbial $\alpha$-amylases: a biotechnological perspective. Process Biochemistry, Oxford, v. 38, n. 11, p.15991616, 2003. http://dx.doi.org/10.1016/S0032-9592(03)00053-0

KLICH, M. A.; PITT, J. L. A Laboratory Guide to Common Aspergillus Species and Their Telemorphs. Australia: Commonwealth Scientific and Industrial Research Organization, 1988. $116 \mathrm{p}$.

KNOB, A.; TERRASAN, C. R. F.; CARMONA E. C. $\beta$-Xylosidases from filamentous fungi: an overview. World Journal of Microbiology and Biotechnology. Netherlands, v. 26, n. 3, p.389-407, 2010. http://dx.doi.org/10.1007/s11274-009-0190-4 LOWRY, O. H.; ROSEBROUGH, N. J.; FARR, A. L.; RANDALL, R. J. Protein Measurement with the Folin Phenol Reagent. The Journal of Biological Chemistry, Maryland, v. 193, n. 1, p. 265-275, 1951.

MILLER, G. L. Use of dinitrosalicylic acid reagent for determination of reducing sugar. Analytical Chemistry, Washington, v. 31, n. 3, p. 426-428, 1959. http://dx.doi.org/10.1021/ac60147a030 
Production and action of an Aspergillus phoenicis enzymatic pool using different carbon sources BENASSI, V. M. et al.

PEIXOTO-NOGUEIRA, S. C.; MICHELIN, M.; BETINI, J. H. A.; JORGE, J. A.; TERENZI, H. F.; POLIZELI, M. L. T. M. Production of xylanase by Aspergilli using alternative carbon sources: application of the crude extract on cellulose pulp biobleaching. Journal of Industrial Microbiology and Biotechnology, Netherlands, v. 36, n. 1, p. 149-155, 2009. http://dx.doi. org/10.1007/s10295-008-0482-y

POLIZELI, M. L. T. M.; JORGE, J. A.; TERENZI, H. F. Effect of the carbon source on the $\beta$-glucosidase system of the thermophilic fungus Humicola grisea. World Journal of Microbiology and Biotechnology, Netherlands, v. 12, n. 3, p. 297-299, 1996. http:// dx.doi.org/10.1007/BF00360933

RAPER, K. B.; FENNELL, D. I. The Genus Aspergillus. Baltimore: The Williams \& Wilkins Company, 1965. 204 p.

RIZZATTI, A. C. S.; JORGE, J. A.; TERENZI, H. F.; RECHIA, C.G. V.; POLIZELI, M. L. T. M. Purification and properties of a thermostable extracellular $\beta$-D-xylosidase produced by a thermotolerant Aspergillus phoenicis. Journal of Industrial Microbiology and Biotechnology, Netherlands, v. 26, n. 3, p.156-160, 2001. http://dx.doi.org/10.1038/sj.jim.7000107

RIZZATTI, A. C. S.; SANDRIM, V. C.; JORGE, J. A.; TERENZI, H. F.; POLIZELI, M. L. T. M. Influence of temperature on the properties of the xylanolytic enzymes of the thermotolerant fungus Aspergillus phoenicis. Journal of Industrial Microbiology and Biotechnology, Netherlands, v. 31, n. 2, p. 88-93, 2004. http:// dx.doi.org/10.1007/s10295-004-0120-2

ROSSELL, C. E. V. Conversion of lignocellulose biomass (bagasse and straw) from the sugar-alcohol industry into bioethanol. In: FRANCO, T. T. Industrial Perspectives for Bioethanol. São Paulo: UNIEMP, 2006. chap. 8, v. 4, p.123-142. (Coleção UNIEMP Inovação).

ROYER, J. C.; NAKAS, J. P. Interrelationship of xylanase induction and cellulase induction of Trichoderma Iongibrachiatum. Applied and Environmental Microbiology, Washington, v. 56, n. 8, p. 2535-2539, 1990.

SILVA, T. M.; ALARCON, R. F.; DAMASIO, A. R. L.; MICHELIN, M.; MALLER, A.; MASUI, D. C.; TERENZI, H. F.; JORGE, J. A.; POLIZELI, M. L. T. M. Use of cassava peel as carbon source for production of amylolytic enzymes by Aspergillus niveus. International Journal of Food Engineering, Berlin, v. 5, n. 5, p.1-11, 2009. http://dx.doi.org/10.2202/1556-3758.1629

SOMERA, A. F.; PEREIRA, M. G.; GuimARÃES, L. H. S.; POLIZELI, M. L. T. M.; TERENZI, H. C.; FURRIEL, R. P. M.; JORGE, J. A. Effect of glycosy lation on the biochemical properties of $\beta$-xylosidases from Aspergillus versicolor. The Journal of Microbiology, Korea, v. 47, n. 3, p. 270-276, 2009. VANDENBERG, L. P. S.; SOCCOL, C. R.; PANDEY, A.; LEBEA, J. M. Solid-state fermentation for the synthesis of citric acid by Aspergillus niger. Bioresource Technology, Oxford, v. 74, n. 2, p.175-178, 2000. http://dx.doi.org/10.1016/S09608524(99)00107-8

VOGEL, H. F. Distribution of lysine pathways among fungi: evolutionary implications. The American Naturalist, Chicago, v. 98, n. 903, p. 435-446, 1964. 